\title{
The effect of tax regulation on firm value: the Turkish case of Allowance for Corporate Equity $(A C E)$ regulation
}

\section{Melisa Ozdamar , Basak Tanyeri \& Levent Akdeniz}

To cite this article: Melisa Ozdamar , Basak Tanyeri \& Levent Akdeniz (2021) The effect of tax regulation on firm value: the Turkish case of Allowance for Corporate Equity (ACE) regulation, Applied Economics Letters, 28:4, 264-268, DOI: 10.1080/13504851.2020.1751797

To link to this article: https://doi.org/10.1080/13504851.2020.1751797

\section{Published online: 20 Apr 2020.}

Submit your article to this journal 둔

Џll Article views: 143

Q View related articles

View Crossmark data \lceil 


\title{
The effect of tax regulation on firm value: the Turkish case of Allowance for Corporate Equity (ACE) regulation
}

\author{
Melisa Ozdamar, Basak Tanyeri and Levent Akdeniz \\ Faculty of Business Administration, Bilkent University, Cankaya, Ankara, Turkey
}

ABSTRACT

Investors ex-ante price the tax shield that Turkish firms would enjoy and react positively to the introduction of a legislation that provides a deduction for new equity issues. Not all firms are equally affected by the equity tax shield. Cumulative abnormal returns prove significantly higher for levered firms who may find it easier to switch from debt to equity financing and for firms that have income to shield from tax. Furthermore, the most levered firms and the firms with the highest income, whom investors ex-ante expect to benefit most from the regulation, do indeed issue more equity to take advantage of the tax benefits of the new regulation.
KEYWORDS

Allowance for corporate equity; tax shield for equity; tax regulation; event study

JEL CLASSIFICATION $\mathrm{G} 38 ; \mathrm{H} 25 ; \mathrm{K} 34$

\section{Introduction}

Modigliani and Miller (1963) started a large literature on how tax benefits of debt affect capital structure decisions. ${ }^{1}$ Debt financing provides a tax shield since interest expense is tax deductible. In most countries around the world, equity financing does not provide the tax shield that debt financing does. IFS Capital Taxes Group (1991) and Devereux and Freeman (1991) proposed a new tax regulation (Allowance for Corporate Equity - ACE-) that provides a deduction for equity issues when a company calculates its taxable profits. ${ }^{2}$ Croatia in 1994 is the first country to enact ACE (Keen and King 2002). So far, Brazil in 1996, Italy in 1997, Austria in 2000, Belgium in 2006, and Turkey in 2015 implemented the regulation that provides a tax shield for equity financing.

We investigate whether and how the introduction of a regulation that provides a tax deduction for equity financing affects shareholder value in Turkish firms listed on Borsa Istanbul. We find that investors price the introduction of ACE as positive news. Furthermore, abnormal returns prove significantly higher for levered firms who may find it easier to switch from debt to equity financing and for firms that have income to shield from tax. We also find that firms in the highest leverage and income bins increase cash equity more than firms in the lowest leverage and income bins. Difference-in-difference analysis shows that the firms which the market ex-ante prices to benefit most from the tax regulation do ex-post raise more equity relative to firms which the market expects to benefit least.

This study contributes to the literature on how tax regulation in general and ACE in particular affect stock market pricing of firms and corporate decision-making. To our knowledge, this is the first empirical study that investigates whether and how investors price the introduction of ACE. The literature on ACE focuses on how the regulation affects tax revenue (Keen and King 2002; Oropallo and Parisi 2007) and changes the financing decision of the firm (Staderini 2001; Klemm 2007; Princen 2012). We focus on investor reaction to the ex-ante anticipated effect of the tax regulation and the expost change in the capital structure of sample firms. The very short-term abnormal returns observed around introduction of the equity tax shield provide a clean measure of how investors price the tax shield that the new regulation brings. Furthermore, the results indicate that market expectations on who

CONTACT Melisa Ozdamar melisa.yilmaz@bilkent.edu.tr; Faculty of Business Administration, Bilkent University, 06800 Cankaya, Ankara, Turkey This article has been republished with minor changes. These changes do not impact the academic content of the article.

This paper is a part of Melisa Ozdamar's Ph.D. thesis in the Faculty of Business Administration in I.D. Bilkent University.

This paper was presented at Bilkent University brown bag seminars and the 2018 Conference on Empirical Legal Studies. We thank Nejat Seyhun, Zeynep Onder, Isil Sevilay Yilmaz and Anthony Niblett for helpful suggestions and comments.

${ }^{1}$ Refer to Graham (2013), Feld et al. (2013) and Graham and Leary (2011) for excellent reviews on the literature that studies how taxes affect capital structure.

${ }^{2}$ Refer to IFS Capital Taxes Group (1991) and Isaac (1997) for discussion and viability of ACE regulation.

○ 2020 Informa UK Limited, trading as Taylor \& Francis Group 
will benefit most from the regulation are validated by the ex-post financing decision to issue equity.

The remainder of the paper is organized as follows. We describe our sampling framework and method in Section 2. Section 3 discusses the empirical results and, finally, Section 4 concludes.

\section{Sampling Framework and Research Method}

We first identify the announcement date of ACE. We conduct keyword searches in Bloomberg and archives of three major Turkish newspapers. The announcement date, 17 March 2015 (Day [0]), is the date when specifics of ACE are revealed and discussed in The Grand National Assembly of Turkey. ${ }^{3}$ The equity tax shield, which allows firms to deduct $50 \%$ of new stock issues multiplied by the average loan interest rate (as determined by The Central Bank of the Republic of Turkey) from their taxable income, entered into force on 1 July $2015 .{ }^{4,5}$ The regulation aims to encourage firms to issue equity instead of debt. ${ }^{6}$ A firm that needs to raise outside capital can issue debt or equity. In Turkey, 100\% of interest payments on debt are tax deductible whereas ACE offers a deduction rate of $50 \%$ on equity. For the average Turkish firm, 1 TL of additional debt offers a tax shield of $t^{*} \mathrm{i}$ TL (where $t$ is the corporate tax rate and $\mathrm{i}$ is the borrowing cost) whereas 1 TL of additional equity offers a tax shield of $\mathrm{t}^{\star} \mathrm{i}^{\star} 0.50$ (where we assume that the average loan rate used in ACE which is set by the Central Bank equals 'i', the borrowing cost of the average Turkish firm). Debt still offers a 50\% more tax shield than equity for the average Turkish corporation. However, compared to before, ACE halves the tax benefits of debt relative to equity. Allowance for Corporate Equity regulation applies to all firms incorporated in Turkey except for financial institutions (such as banks and insurance companies) and government-owned enterprises. Our sample covers the 89 non-financial firms in the BIST-100 Index (the main index for Borsa Istanbul).

We adopt the event study method of Brown and Warner (1985) to measure the market reaction to the ACE regulation. ${ }^{7}$ We calculate daily returns for each stock starting 304 trading days before the announcement (event date) and ending 20 trading days after the announcement using adjusted share prices from DataStream. The estimation window covers 229 trading days before the event window (Day [-304, -75]). The event window starts 75 trading days before and ends 20 trading days after the announcement date (Day $[-74,+20])$. We start the event window 75 trading days before 17 March 2015 since on 29 December 2014 the chairman of Capital Markets Board of Turkey talked about the prospect of introducing a tax shield for equity financing. ${ }^{8}$ We do not consider 29 December 2014 as the event date since the specifics and coverage of the regulation was not revealed. We measure investor reaction to the tax regulation using abnormal returns that difference realized returns in the event window from the mean of returns in the estimation window. ${ }^{9}$

\section{Empirical Results and Discussion}

Abnormal returns on the announcement date for the 89 non-financial firms covered in the tax bill average $2 \%$ and prove statistically significant. Cumulative abnormal returns (CAR) in the three-day window around the announcement date average $3 \%$ and are also statistically significant. ${ }^{10}$ Investors evaluate the

\footnotetext{
${ }^{3}$ The newspaper account of discussions in The Grand National Assembly of Turkey is available at https://www.haberler.com/torba-kanun-teklifi-tbmm-plan-vebutce-komisyonu-7082528-haberi/.

${ }^{4}$ Interested readers may refer to http://www.resmigazete.gov.tr/eskiler/2015/04/20150407-19.htm for the full tax bill.

${ }^{5}$ The tax bill demonstrates how the tax deduction for new equity issues will work with the following example. Assume Company XYZ issues additional equity of 1 TL as of 1 January 2016. Average loan interest rate (as determined by The Central Bank of the Republic of Turkey) is $13.57 \%$ as of 31 December 2016 . Then, the equity tax deduction is as follows: Increase in equity $\times$ Loan interest rate $\times$ Time $\times$ Deduction rate $=1 \mathrm{TL} \times 13.57 \% \times(12 / 12) \times 50 \%=0.06785 \mathrm{TL}$. The tax shield using the 20 percent corporate tax rate for a $1 \mathrm{TL}$ increase in equity corresponds to $0.01357 \mathrm{TL}$ in the year of the issue. Firms increasing cash capital benefit from the tax shield of $0.01357 \mathrm{TL}$ not only in the year of issue but also in every year following the issue. Hence, the net present value of future tax shields arising from the 1 TL increase in equity (using the Central Bank's loan interest rate of $13.57 \%$ and the perpetuity formula $0.01357 / 0.1357$ ) will be 0.10 TL. In case of subsequent capital reductions, the reduced amount of capital is not taken into account in the tax shield calculation. Interested readers may refer to http://www.resmigazete.gov.tr/eskiler/2016/03/20160304-9.htm.

${ }^{6} \mathrm{ACE}$ regulation in Turkey offers a notional interest deduction (NID) from incremental cash capital against the effective interest cost deduction of debt. The aim is to address the debt bias in corporate sector. Refer to Zangari (2014) for the comparison of how Italy and Belgium practice ACE to eliminate the debt bias.

${ }^{7}$ Refer to MacKinlay (1997) and Krivin et al. (2003) for excellent reviews on the literature for event study method and Basdas and Oran (2014) on event studies that focus on Turkey.

${ }^{8}$ The specifics of the Chairperson's televised statement are available at https://www.bloomberght.com/haberler/haber/1692619-spkertas-forexte-kayipkazancorani-yuzde-87.

${ }^{9}$ We use the mean-adjusted model to calculate abnormal returns. Unreported results available upon request are robust to using other models such as the market model. We do not use the market model as our benchmark model since sample firms constitute $89 \%$ of the market index and we would be taking the average of abnormal returns coming from a weighted average of the sample returns.

${ }^{10}$ Five-day CARs $(2.88 \%)$ and seven-day CARs $(2.62 \%)$ indicate qualitatively similar results.
} 
Table 1. Differences in market reaction to the ACE tax regulation.

\begin{tabular}{lccc}
\hline & \multicolumn{2}{c}{ Panel A - Market reaction to the tax bill according to firm leverage } \\
\cline { 2 - 4 } & \multicolumn{1}{c}{ Equity to Debt bins } \\
\cline { 2 - 4 } AR (event date) & 1 - Least Levered & 2 & $3-$ Most Levered \\
& 1.21 & 2.38 & 2.43 \\
CAR $[-1,+1]$ & 0.95 & $2.44^{* *}$ & $2.05^{* *}$ \\
& 2.65 & 2.73 & $2.15^{* *}$ \\
\# of observations & 1.60 & 1.62 & 3.88 \\
\hline
\end{tabular}

Panel B - Market reaction to the tax bill according to income stream

\begin{tabular}{lccc}
\hline & & EBIT to Asset bins & \\
\cline { 2 - 4 } & 1 - Highest Income & 2 & $3-$ Lowest Income \\
\hline AR (event date) & 2.25 & 1.96 & 1.80 \\
& $2.23^{* *}$ & $2.03^{*}$ & $1.81^{*}$ \\
CAR $[-1,+1]$ & $1.85^{*}$ & $2.81^{*}$ & 1.58 \\
& $4.96^{*}$ & 1.46 & 1.79 \\
\# of observations & $2.84^{* * *}$ & 1.47 & 1.04 \\
\hline
\end{tabular}

Table reports abnormal returns on and three-day CARs around the announcement date in subsamples of firms classified according to equity-to-debt ratio in Panel A and EBIT-to-asset ratio in Panel B. Equity-to-debt ratio is book value of owners' equity (in cash) divided by total debt as of the end of 2014. EBIT-toasset ratio is EBIT divided by total assets as of the end of 2014. The stocks are sorted from the highest to lowest ratios and divided into three bins. Abnormal returns (AR) and cumulative abnormal returns (CAR) reported in the first and fourth rows are in percentages. Brown and Warner t-statistics are reported in second and fifth rows. Corrado t-statistics are reported in third and sixth rows. The seventh rows show the number of observations. ${ }^{* * *}$, ${ }^{* *}$ and ${ }^{*}$ denote significance at $1 \%, 5 \%$ and $10 \%$, respectively.

tax shield proposed in ACE as positive news and price the tax shield at the announcement. Investors that have not yet observed any changes in capital structure anticipate the future increase in equity issuance and price the expected value of the tax shield that would result from the increase in equity issues. The literature starting with Staderini (2001) in Italy, Keuschnigg and Dietz (2007) in Switzerland, Princen (2012) in Belgium, Finke et al. (2014) in Germany, and Petutschnig and Rünger (2017) in Austria document that firms do indeed issue more equity after the introduction of tax incentives for equity issuance.

ACE regulation states that firms who increase cash capital after 1 July 2015 can benefit from the tax incentive. We hypothesize that levered firms have more room to increase equity capital. Market reaction to the ACE announcement should then be higher in firms with lower equity-to- debt ratios. We sort the 89 non-financial firms in the sample into three bins of 30,30 and 29 firms, respectively, according to their equity-to-debt ratio. Panel A of Table 1 reports abnormal returns on and three-day CARs around the announcement date in the three bins sorted according to leverage. Investor reaction to ACE announcement is most pronounced in the most levered firms (CARs of $3.88 \%$ and statistically significant) and least pronounced in the leastlevered firms (CARs of $2.65 \%$ and statistically insignificant). ${ }^{11}$ In line with our hypothesis that levered firms with room to increase their equity capital may benefit more from the tax shield, abnormal returns increase across the equity-to-debt bins.

Firms can benefit from the tax bill only if they have income to shield. Thus, we hypothesize that market reaction to ACE for firms with large income streams will be more pronounced. We use EBIT (earnings before interest and taxes) normalized by total assets to measure the relative magnitude of income. We sort the 89 non-financial firms into three bins of 30,30 and 29 firms, respectively, according to their EBIT-to-asset ratio. Panel B of Table 1 reports abnormal returns on and three-day CARs around the announcement date in the three bins of 30, 30 and 29 firms. Investor reaction to the announcement of ACE increases in the level of income that the firm can protect from tax. Three-day CARs for the 30 (29) firms with

\footnotetext{
${ }^{11}$ Statistical tests using Brown and Warner (1985) and Corrado (1989) prove similar.
} 
Table 2. Differences in book value of owners' equity (in cash).

\begin{tabular}{|c|c|c|c|c|c|}
\hline \multicolumn{6}{|c|}{ Panel A - Differences in the lowest and highest equity-to-debt ratio bin } \\
\hline & 2015 & 2016 & 2017 & 2018 & \# of observations \\
\hline Full Sample & 40.05 & 77.33 & 87.24 & 123.47 & 89 \\
\hline Most Levered & 2.80 & 90.57 & 91.75 & 189.32 & 29 \\
\hline Least Levered & 6.20 & 11.40 & 18.69 & 23.24 & 30 \\
\hline Difference-in-difference & -3.41 & 79.17 & 73.06 & 166.08 & \\
\hline & -1.06 & 1.08 & 1.00 & $1.75^{*}$ & \\
\hline \multicolumn{6}{|c|}{ Panel B - Differences in the highest and lowest EBIT-to-asset ratio bin } \\
\hline & 2015 & 2016 & 2017 & 2018 & \# of observations \\
\hline Full Sample & 40.05 & 77.33 & 87.24 & 123.47 & 89 \\
\hline Highest Income & 108.82 & 188.27 & 192.59 & 198.26 & 29 \\
\hline Lowest Income & 6.93 & 15.05 & 28.77 & 129.44 & 30 \\
\hline \multirow[t]{2}{*}{ Difference-in-difference } & 101.89 & 173.21 & 183.82 & 68.81 & \\
\hline & 0.93 & $1.74^{*}$ & 1.26 & 0.45 & \\
\hline
\end{tabular}

the largest (smallest) income stream are 4.96 (1.79) percent and statistically significant (insignificant). ${ }^{12,13}$

We analyse whether the ex-ante expectations of the market on which firms will benefit most from the regulation is validated by the ex-post equity issuance of sample firms. We conduct a difference-indifference (DID) analysis ${ }^{14}$ and compare the increase in cash equity in the one-, two-, three- and four-years following ACE in the full sample and in the subsamples of firms classified according to equity-to-debt and EBIT-to-asset ratios. The percentage increase in cash equity averages $40 \%, 77 \%, 87 \%$ and $123 \%$ at the end of 2015, 2016, 2017 and 2018 (all statistically significant increases except for 2015), respectively. Panel A of Table 2 shows that firms in the mostlevered bin increase their equity capital by $91 \%$ in 2016, 2 years after the passing of ACE, relative to 2014, the last year before ACE was introduced whereas the increase in cash capital for the least levered bin is $11 \%$. Panel B of Table 2 reports that firms in the highest income bin increase cash equity by $188 \%$ between 2014 and 2016 whereas firms in the lowest income bin raise cash equity by $15 \% .{ }^{15}$ Firms that the market expects to benefit most from the tax regulation (as measured by the abnormal returns around announcement) do indeed issue more equity relative to other firms.

\section{Conclusion}

The three-day cumulative abnormal returns around the announcement of ACE average 3\% for non-financial firms that are covered in the tax bill. Furthermore, not all firms are equally affected by the tax bill. Investors differentiate between firms who will potentially benefit more from the tax shield based on the level of leverage and income stream. Furthermore, the ex-ante expectations of the market are corroborated by the ex-post equity issuance of sample firms. Our findings are novel in that we show how tax regulations that allow for equity tax shields change corporate decisionmaking and how investors ex-ante price the effect of these changes.

Our results are specific to listed (public) firms due to lack of data on private firms. Results may not generalize to private (non-listed) firms since their ability to access debt and equity markets might differ (Goyal et al., 2011; López-Gracia and Sogorb-Mira,

\footnotetext{
${ }^{12}$ Market reaction differs according to industry. Abnormal returns in communications, consumer goods and utilities prove significant and returns in technology, real estate, basic materials, and conglomerate industries prove insignificant.

${ }^{13}$ We also test market reaction for firms sorted according to their age and size (Beck et al. 2006; Farre-Mensa and Ljungqvist 2016). Abnormal returns in the three bins sorted according to age and size do not exhibit a clear difference in one direction. Results are available upon request.

${ }^{14}$ We thank the anonymous referee for this suggestion. Refer to An (2012), Panier et al. (2015) and Clemente-Almendros and Sogorb-Mira (2016) for similar examples of difference-in-difference (DID) analysis.

${ }^{15}$ For example, Afyon Cimento Sanayi issued 97 million TL cash equity as of 24 July 2015 . The recognized equity tax deduction in 2015 and 2016 financial reports was 7.11 million and 16.45 million $T L$, respectively.
} 
2014). Therefore, the results reported here might not be extrapolated to a general firm context. Furthermore, the results are also specific to Turkish firms. In future work, we aim to investigate cross-country differences in investor reaction to tax regulation that provides tax shield to equity.

\section{Disclosure statement}

No potential conflict of interest was reported by the authors.

\section{References}

An, Z. 2012. “Taxation and Capital Structure: Empirical Evidence from a Quasi-experiment in China." Journal of Corporate Finance 18 (4): 683-689.

Basdas, U., and A. Oran. 2014. "Event Studies in Turkey." Borsa Istanbul Review 14 (3): 167-188.

Beck, T., A. Demirguc-Kunt, L. Laeven, and V. Maksimovic. 2006. "The Determinants of Financial Obstacles." Journal of International Money and Finance 25 (6): 932-952.

Brown, S. J., and J. B. Warner. 1985. "Using Daily Stock Returns: The Case of Event Studies." Journal of Financial Economics 14: 3-31.

Clemente-Almendros, J. A., and F. Sogorb-Mira. 2016. "The Effect of Taxes on the Debt Policy of Spanish Listed Companies." Journal of the Spanish Economic Association (Series) 7: 359-391.

Corrado, C. J. 1989. “A Nonparametric Test for Abnormal Security-price Performance in Event Studies.” Journal of Financial Economics 23 (2): 385-395.

Devereux, M., and H. Freeman. 1991. "A General Neutral Profits Tax.” Fiscal Studies 12 (3): 1-15.

Farre-Mensa, J., and A. Ljungqvist. 2016. "Do Measures of Financial Constraints Measure Financial Constraints?" Review of Financial Studies 29 (2): 271-308.

Feld, L. P., J. H. Heckemeyer, and M. Overesch. 2013. "Capital Structure Choice and Company Taxation: A Meta-study." Journal of Banking \& Finance 37 (8): 2850-2866.

Finke, K., J. H. Heckemeyer, and C. Spengel, 2014. “Assessing the Impact of Introducing an ACE Regime: A Behavioural Corporate Microsimulation Analysis for Germany." ZEW Discussion Paper 14-033.

Goyal, V. K., A. Nova, and L. Zanetti. 2011. "Capital Market Access and Financing of Private Firms." International Review of Finance 11 (2): 155-179.

Graham, J. R. 2013. "Do Taxes Affect Corporate Decisions? A Review.” Vol. 2, Part A, Chapter 3 in Handbook of the Economics of Finance, edited by G. M. Constantinides, M. Harris, and R. M. Stulz, 123210. North Holland: Elsevier.

Graham, J. R., and M. T. Leary. 2011. "A Review of Empirical Capital Structure Research and Directions for the Future." Annual Review of Financial Economics 3: 309-345.

IFS Capital Taxes Group, 1991. Equity for companies: A corporation tax for the 1990s. Commentary 26, Institute for Fiscal Studies (London).

Isaac, J. 1997. "A Comment on the Viability of the Allowance for Corporate Equity.” Fiscal Studies 18 (3): 303-318.

Keen, M., and J. King. 2002. "The Croatian Profit Tax: An ACE in Practice." Fiscal Studies 23 (3): 401-418.

Keuschnigg, C., and M. D. Dietz. 2007. "A Growth Oriented Dual Income Tax." International Tax and Public Finance 14 (2): 191-221.

Klemm, A. 2007. "Allowances for Corporate Equity in Practice.” CESifo Economic Studies 53 (2): 229-262.

Krivin, D., R. Patton, E. Rose, and D. Tabak. 2003. Determination of the Appropriate Event Window Length in Individual Stock Event Studies. NERA Economic Consulting. Available at SSRN: https://ssrn.com/abstract= 466161 or http://dx.doi.org/10.2139/ssrn.466161

López-Gracia, J., and F. Sogorb-Mira. 2014. "Sensitivity of External Resources to Cash Flow under Financial Constraints." International Business Review 23 (5): 920-930.

MacKinlay, A. C. 1997. "Event Studies in Economics and Finance." Journal of Economic Literature 35 (1): 13-39.

Modigliani, F., and M. H. Miller. 1963. "Corporate Income Taxes and the Cost of Capital: A Correction." American Economic Review 53 (3): 433-443.

Oropallo, F., and V. Parisi. 2007. "Will Italy's Tax Reform Reduce the Corporate Tax Burden? A Microsimulation Analysis." Rivista Di Statistica Ufficiale 9 (1): 31-58.

Panier, F., F. Pérez-González, and P. Villanueva, 2015. "Capital Structure and Taxes: What Happens When You (Also) Subsidize Equity?” Mimeo, BIS Conference, Bank for International Settlements, Basel.

Petutschnig, M., and S. Rünger, 2017. "The Effects of a Tax Allowance for Growth and Investment - Empirical Evidence from a Firm-level Analysis.” WU International Taxation Research Paper Series No.2017-09.

Princen, S., 2012. “Taxes Do Affect Corporate Financing Decisions: The Case of Belgian ACE.” CESifo Working Paper Series 3713. Staderini, A., 2001. "Tax Reforms to Influence Corporate Finance Policy: The Case of the Italian Business Tax Reform of 1997-98.” Temi di discussione (Economic working papers) 423.

Zangari, E., 2014. "Addressing the Debt Bias: A Comparison between the Belgian and the Italian ACE Systems." Taxation Paper No.44, European Commission. 